\title{
LECTURE
}

\section{Pathogenesis of Gastritis in Ileitis-prone SAMP1/Yit Mice}

\author{
Peter B. Ernst, ${ }^{1}$ Elizabeth B. Wiznerowicz, ${ }^{1}$ Sandford H. Feldman ${ }^{2}$ and Kenneth S. Tung ${ }^{3}$ \\ ${ }^{1}$ Department of Medicine, University of Virginia, Virginia, USA \\ ${ }^{2}$ The Center for Comparative Medicine, University of Virginia, Virginia, USA \\ ${ }^{3}$ Department of Pathology, University of Virginia, Virginia, USA
}

(Received for publication on November 5, 2010)

(Revised for publication on December 1, 2010)

(Accepted for publication on December 16, 2010)

\begin{abstract}
Inflammatory bowel disease is a chronic inflammatory disease of the gut which manifests as ulcerative colitis or Crohn's disease. One of the most studied animal models of spontaneous Crohn's disease is the senescence-accelerated mouse (SAMP1/Yit strain) model. ${ }^{1}$ In SAMP1/Yit mice, although many immunological responses are perturbed, some evidence suggests that the primary defect lies in the epithelial cell barrier. In the process of studying epithelial permeability, we observed that the stomach in SAMP1/ Yit mice also had increased permeability. Upon further examination, these mice were shown to have marked, chronic gastritis with focal to diffuse aggregates of mononuclear cells of mixed lineages. These aggregates were located predominantly in the oxyntic mucosa, with occasional lesions in the forestomach but with relatively fewer cellular infiltrates in the antral mucosa. Real-time reverse transcription (RT) PCR showed an increase in several helper T cell (Th cell)-derived pro-inflammatory cytokines in the gastric mucosa of SAMP1/Yit mice. However, many of the cells in the aggregates of SAMP1/Yit mice were B cells. SAMP1/Yit B cells exacerbate ileitis when co-transferred into immunodeficient recipients. The gastritis also reflects a contribution by B cells. As SAMP1/Yit mice were derived from AKR mice, we examined AKR mice and determined that they too have an increased occurrence of gastritis, although they do not develop ileitis. B cells contributed to the gastric inflammation in these mice also. Thus, SAMP1/Yit mice display gastritis as well as ileitis, and B cells appear to play a role in the pathogenesis of inflammation at both sites. This lecture will discuss some of the mechanisms that may account for these different manifestations of gastrointestinal disease. (Keio J Med 60 (2) : 65-68, June 2011)
\end{abstract}

Keywords: gastritis, ileitis, Crohn's disease, B cell

\section{Introduction}

The gastrointestinal tract faces the unique immunological challenge of coping with a dynamic and vast array of dietary and microbial antigens. Chronic inflammatory disease of the intestine as well as the stomach of adults and children ${ }^{2-4}$ arises in genetically susceptible individuals that fail to properly regulate host responses to these luminal antigens. The importance of gastrointestinal infections in Japan is illustrated by the frequency of Helicobacter pylori infection ${ }^{5}$ and its key role in the pathogenesis of gastric cancer. ${ }^{6,7}$ Another example of chronic inflammatory disease in the gut is inflammatory bowel disease, which manifests as ulcerative colitis or Crohn's disease. Crohn's disease tends to affect the terminal il- eum, but in humans, the disease can arise virtually anywhere within the gastrointestinal tract.

\section{Animal Models of Inflammatory Bowel Disease}

For many years, it was believed that intestinal immune responses were carefully regulated to prevent excessive amounts of inflammation caused by luminal antigens. This notion was confirmed when genetic engineering was applied broadly to manipulate gene expression in mice. It quickly became apparent that disruption of several different genes leads to the development of colitis. ${ }^{8-10}$ It is now appreciated that disrupting the expression of several genes encoding proteins that function in a related signaling pathway often leads to disease. For example,

Reprint requests to: Peter B Ernst, DVM, PhD, Department of Medicine, University of Virginia, Box 8000708, Charlottesville, VA 22908 -0708, USA, E-mail: pernst@virginia.edu

Copyright $(2011$ by The Keio Journal of Medicine. 
deficiencies in $I l-10,{ }^{10}$ its receptor ${ }^{11}$ or downstream signaling molecules ${ }^{12}$ all result in colitis. $\mathrm{Il}-10$ receptors are broadly expressed in cells in the gut ${ }^{13,14}$ and contribute to anti-inflammatory responses. It is intellectually satisfying that an entire pathway related to a receptor, its ligand and signaling molecules all contribute to the control of host responses. However, there are many gene knockout models that target unrelated pathways that still result in the development of intestinal inflammation. For example, mutations affecting the epithelial cell barrier, ${ }^{15}$ nerves,${ }^{16}$ and innate and adaptive responses ${ }^{17,18}$ can all lead to colitis. These observations speak to the diverse aspects of the host response that contribute to the optimal control of the host response to luminal antigens.

While the appearance of intestinal inflammation in various mouse models differs, most of this inflammation is focused in the colon and, in general, provide a better model of ulcerative colitis than Crohn's disease. ${ }^{19}$ In some mouse models, such as the $I l-10$ knockout mouse, inflammation of the small intestine has been observed ${ }^{10}$ in addition to the more common colitis. Two other models, the SAMP1/Yit ${ }^{1,20}$ mouse and the TNF ${ }^{\Delta A R E 21,22}$ mouse, develop inflammation in the terminal ileum rather that the colon and thus are often preferred as a model with which to study Crohn's disease.

\section{The Role of the Microbiome in Gastrointestinal Inflammation}

While luminal antigens, particularly microbes, have long been believed to be factors that trigger or ameliorate disease, direct evidence supporting this notion has emerged with the use of gnotobiotic mice. When colitisprone mice are housed in germ-free conditions, almost all of the strains remain healthy. ${ }^{2}$ For example, germ-free $\mathrm{Il}$ 10 -deficient mice do not develop disease. ${ }^{23}$ Using germfree mice, it is possible to identify a single species, or a limited numbers of species, as triggers of gastroenteric disease. While the intestinal microbe Helicobacter hepaticus can exacerbate disease in Il-10-deficient mice, ${ }^{24}$ it was insufficient to trigger colitis in germ-free mice. ${ }^{23}$ In fact, in wildtype mice, $H$. hepaticus induces a regulatory helper $\mathrm{T}$ cell that prevents inflammation by this organism. ${ }^{25}$ While some bacteria may promote disease ${ }^{26}$ and others attenuate it, ${ }^{27}$ in general, colitis that occurs in various knockout mice results from an inappropriate intestinal immune and inflammatory response to the normal gastrointestinal microbiome that is usually not pathogenic in wildtype mice. This is consistent with the fact that so many genetically engineered mice develop colitis spontaneously without any intentional manipulation of their microbiome.

\section{Characterization of the SAMP1/Yit Mouse as a Model of Crohn's Disease}

Senescence-accelerated mouse (SAM) strains were originally derived from AKR mice. ${ }^{28}$ One of these strains, the SAMP1/Yit mouse, was subsequently shown to have many manifestations resembling human Crohn's disease, including discontinuous and transmural chronic inflammation of the terminal ileum and, in some cases, perianal fistulae. ${ }^{1,20,29}$ Other studies have shown that ileitis is associated with pro-inflammatory cytokine production - Th1 responses in younger mice ${ }^{20}$ but also Th2 cytokines, ${ }^{30}$ particularly as the mice mature. ${ }^{31}$

\section{Extraintestinal Manifestations in the SAMP1/Yit Mouse}

Although many immunological responses are perturbed in the SAMP1/Yit mouse, some evidence suggests that the primary defect lies in the epithelial cell barrier. In the process of studying intestinal epithelial permeability, ${ }^{32}$ we showed that the stomach in SAMP1/ Yit mice also has a disrupted epithelial cell barrier function. ${ }^{33}$ Upon further examination, it became obvious that the permeability defect in the SAMP1/Yit stomach was associated with marked gastritis (Ernst et al, manuscript in preparation). The histological changes include focal to diffuse aggregates of mononuclear cells of different lineages, including $\mathrm{CD}^{+} \mathrm{T}$ cells and $\mathrm{B} 220^{+} \mathrm{B}$ cells. These aggregates are located predominantly in the oxyntic mucosa with occasional lesions in the forestomach, but with fewer cellular infiltrates in the antral mucosa. Inflammation in the oxyntic mucosa mimics that in the gerbil model of $H$. pylori-induced gastritis and parietal cell atrophy. ${ }^{6}$ Infiltration with polymorphonuclear cells (including neutrophils) was remarkably modest. Realtime RT PCR shows an increase in many of the pro-inflammatory $\mathrm{Th}$ cell-derived cytokines in the gastric mucosa of SAMP1/ Yit mice (Ernst et al, manuscript in preparation).

The majority of cells in the gastric aggregates of SAMP1/Yit mice are B cells. As SAMP1/Yit mice are derived from AKR mice, we examined AKR mice and determined that they too have significant gastritis. B cells also contribute to the gastric inflammation in AKR mice.

$\mathrm{B}$ cells appear to have pathogenic roles in multiple tissues. The recruitment of $B$ cells exacerbates inflammation in the ileum ${ }^{34}$; this recruitment is dependent on beta 7 integrin. ${ }^{35}$ The role of these B cells in the pathogenesis of ileitis is not entirely clear. It has been suggested that B cells from SAMP1/Yit mice express glucocorticoid-induced TNFR-related protein (GITR) ligand which, when engaged into its receptor GITR, decreases the function of regulatory helper T cells. ${ }^{34}$ Interestingly, B cells in SAMP1/Yit mice produce less $I l-10$ and TGF- $\beta,{ }^{36}$ which may affect their function and favor a role in the pathogenesis of inflammation. Thus, it is possible that the B 
cell defect(s) in SAMP1/Yit mice affects their regulatory function; these defective B cells could contribute directly to inflammation, perhaps through the production of antibodies leading to immune complex-mediated damage.

In the original description of the disease in SAMP1/Yit mice, the authors reported "no significant extraintestinal manifestations" detected in the stomach, liver, spleen, thymus and various lymph nodes. ${ }^{20}$ Subsequently, it became clear that these mice also have some skin lesions as well as mononuclear cell aggregates in their livers, ${ }^{1}$ and, based on our studies, gastritis. There are several possible explanations for this discrepancy. First, there could be genetic drift between strains housed at different institutions. While possible, this seems unlikely since SNP analysis of the founding and current strains at our institution appear genetically identical (Drs. Jesus Rivera-Nieves and M. McDuffie, personal communication). Moreover, SAMP1/ Yit mice were originally derived from AKR mice, ${ }^{28}$ which also develop gastritis. Thus, the tendency to develop gastritis may lie in the AKR background that is embedded in SAMP1/Yit mice. Another interesting avenue to explore is the role of epigenetic control of the disease.

The inability to detect gastritis previously could have been due to differences in the microbiome in the mice now compared to the initial studies. This is indeed possible because bacteria can at least exacerbate and/or hasten the onset of lesions in SAMP1/Yit mice. In other cases, the presence of certain bacterial species can attenuate the ileitis. ${ }^{37-39}$ (It should be noted that, in view of the presence of gastritis, the effects of inflammation on gastric $\mathrm{pH}$ may favor the ability of probiotics to be protective, and, in turn, these bacteria may not necessarily colonize human Crohn's disease patients that have normal gastric acid.) Importantly, histological review of stomachs from germ-free mice shows occasional evidence of the aggregates that are typical of this form of gastritis (unpublished observation 2005), and inflammatory changes are also found in the ileum. ${ }^{40}$ Thus, inflammation in the gastrointestinal tract of SAMP1/Yit mice is not entirely dependent on a full microbiome, although it is exacerbated by the presence of microbial communities. It is possible that dietary antigens or microbial products within mouse chow were sufficient to trigger these lesions; however, further study is required. A very likely factor in the failure to recognize gastritis in SAMP1/Yit mice previously is that many scientists reviewing histology in murine models may not have a complete awareness of some of the subtle aspects of comparative pathology. Thus, they may have simply failed to recognize gastritis in these animals, especially if they were being compared with AKR, which also have gastritis.

\section{Summary}

In summary, the SAMP1/Yit mouse continues to provide an interesting model for studying the pathogenesis of inflammatory diseases. However, disease in these mice is not limited to the ileum but is also manifest broadly in the skin, liver and, in particular, the stomach. How these lesions relate to each other and whether they reflect a common mechanism related to the pathogenesis of Crohn's disease remains unclear. It is more likely that they differ significantly in their tissue-specific pathogenesis, but distinct pro-inflammatory mechanisms may emerge due a general defect in SAMP1/Yit mice.

\section{References}

1. Matsumoto S, Okabe Y, Setoyama H, Takayama K, Ohtsuka J, Funahashi H, Imaoka A, Okada Y, Umesaki Y: Inflammatory bowel disease-like enteritis and caecitis in a senescence accelerated mouse P1/Yit strain. Gut 1998; 43: 71-78.[Medline] [CrossRef]

2. Sartor RB: Microbial influences in inflammatory bowel diseases. Gastroenterology 2008; 134: 577-594.[Medline] [CrossRef]

3. Ernst PB, Peura DA, Crowe SE: The translation of Helicobacter pylori basic research to patient care. Gastroenterology 2006; 130: 188-206.[Medline] [CrossRef]

4. Ernst PB, Gold BD: Helicobacter pylori in childhood: new insights into the immunopathogenesis of gastric disease and implications for managing infection in children. J Pediatr Gastroenterol Nutr 1999; 28: 462-473.[Medline] [CrossRef]

5. Suzuki H, Hibi T, Marshall BJ: Helicobacter pylori: present status and future prospects in Japan. J Gastroenterol 2007; 42: 1-15. [Medline] [CrossRef]

6. Suzuki H, Minegishi Y, Nomoto Y, Ota T, Masaoka T, van Den Brink GR, Hibi T: Down-regulation of a morphogen (sonic hedgehog) gradient in the gastric epithelium of Helicobacter pylori-infected Mongolian gerbils. J Pathol 2005; 206: 186-197.[Medline] [CrossRef]

7. Uemura N, Okamoto S, Yamamoto S, Matsumura N, Yamaguchi S, Yamakido M, Taniyama K, Sasaki N, Schlemper RJ: Helicobacter pylori infection and the development of gastric cancer. $\mathrm{N}$ Engl J Med 2001; 345: 784-789.[Medline] [CrossRef]

8. Mombaerts P, Mizoguchi E, Grusby MJ, Glimcher LH, Bhan AK, Tonegawa S: Spontaneous development of inflammatory bowel disease in T cell receptor mutant mice. Cell 1993; 75: 275-282. [Medline] [CrossRef]

9. Strober W, Ehrhardt RO: Chronic intestinal inflammation: An unexpected outcome in cytokine or T cell receptor mutant mice. Cell 1993; 75: 203-205.[Medline] [CrossRef]

10. Kuhn R, Lohler J, Rennick D, Rajewsky K, Muller W: Interleukin-10-deficient mice develop chronic enterocolitis. Cell 1993; 75: 263-274.[Medline] [CrossRef]

11. Spencer SD, Di Marco F, Hooley J, Pitts-Meek S, Bauer M, Ryan AM, Sordat B, Gibbs VC, Aguet M: The orphan receptor CRF2-4 is an essential subunit of the interleukin 10 receptor. J Exp Med 1998; 187: 571-578.[Medline] [CrossRef]

12. Takeda K, Clausen BE, Kaisho T, Tsujimura T, Terada N, Forster I, Akira S: Enhanced Th1 activity and development of chronic enterocolitis in mice devoid of Stat 3 in macrophages and neutrophils. Immunity 1999; 10: 39-49.[Medline] [CrossRef]

13. Schreiber S, Heinig T, Thiele H-G, Raedler A: Immunoregulatory role of interleukin-10 in patients with inflammatory bowel disease. Gastroenterology 1995; 108: 1434-1444.[Medline] [CrossRef]

14. Denning TL, Campbell NA, Song F, Garofalo RP, Klimpel GR, Reyes VE, Ernst PB: Expression of IL-10 receptors on epithelial cells from the murine small and large intestine. Int Immunol 2000; 12: 133-139.[Medline] [CrossRef]

15. Hermiston ML, Gordon JI: Inflammatory bowel disease and ad- 
enomas in mice expressing a dominant negative $\mathrm{N}$-cadherin. Science 1995; 270: 1203-1207.[Medline] [CrossRef]

16. Savidge TC, Newman P, Pothoulakis C, Ruhl A, Neunlist M, Bourreille A, Hurst R, Sofroniew MV: Enteric glia regulate intestinal barrier function and inflammation via release of S-nitrosoglutathione. Gastroenterology 2007; 132: 1344-1358.[Medline] [CrossRef]

17. Strober W, Fuss I, Mannon P: The fundamental basis of inflammatory bowel disease. J Clin Invest 2007; 117: 514-521.[Medline] [CrossRef]

18. Elson CO, Cong Y, McCracken VJ, Dimmitt RA, Lorenz RG, Weaver CT: Experimental models of inflammatory bowel disease reveal innate, adaptive, and regulatory mechanisms of host dialogue with the microbiota. Immunol Rev 2005; 206: 260-276. [Medline] [CrossRef]

19. Elson CO, Sartor RB, Tennyson GS, Riddell RH: Experimental models of inflammatory bowel disease. Gastroenterology 1995; 109: 1344-1367.[Medline] [CrossRef]

20. Kosiewicz MM, Nast CC, Krishnan A, Rivera-Nieves J, Moskaluk CA, Matsumoto S, Kozaiwa K, Cominelli F: Th1-type responses mediate spontaneous ileitis in a novel murine model of Crohn's disease. J Clin Invest 2001; 107: 695-702.[Medline] [CrossRef]

21. Kontoyiannis D, Pasparakis M, Pizarro TT, Cominelli F, Kollias G: Impaired on/off regulation of TNF biosynthesis in mice lacking TNF AU-rich elements: implications for joint and gut-associated immunopathologies. Immunity 1999; 10: 387-398.[Medline] [CrossRef]

22. Ho J, Kurtz CC, Naganuma M, Ernst PB, Cominelli F, RiveraNieves J:A CD8+/CD103 high T cell subset regulates TNF-mediated chronic murine ileitis. J Immunol 2008; 180: 2573-2580. [Medline]

23. Song F, Ito K, Denning TL, et al: Expression of the neutrophil chemokine $\mathrm{KC}$ in the colon of mice with enterocolitis and by intestinal epithelial cell lines: Effects of flora and proinflammatory cytokines. J Immunol 1999; 162: 2275-2280.[Medline]

24. Kullberg MC, Ward JM, Gorelick PL, Caspar P, Hieny S, Cheever A, Jankovic D, Sher A: Helicobacter hepaticus triggers colitis in specific-pathogen-free interleukin-10 (IL-10)-deficient mice through an IL-12- and gamma interferon-dependent mechanism. Infect Immun 1998; 66: 5157-5166.[Medline]

25. Kullberg MC, Jankovic D, Gorelick PL, Caspar P, Letterio JJ, Cheever AW, Sher A: Bacteria-triggered CD4(+) T regulatory cells suppress Helicobacter hepaticus-induced colitis. J Exp Med 2002; 196: 505-515.[Medline] [CrossRef]

26. Kim SC, Tonkonogy SL, Albright CA, Tsang J, Balish EJ, Braun J, Huycke MM, Sartor RB: Variable phenotypes of enterocolitis in interleukin 10-deficient mice monoassociated with two different commensal bacteria. Gastroenterology 2005; 128: 891-906. [Medline] [CrossRef]

27. Sartor RB: Therapeutic manipulation of the enteric microflora in inflammatory bowel diseases: antibiotics, probiotics, and prebiotics. Gastroenterology 2004; 126: 1620-1633.[Medline] [CrossRef]

28. Takeda T, Hosokawa M, Takeshita S, et al: A new murine model of accelerated senescence. Mech Ageing Dev 1981; 17: 183-194. [Medline] [CrossRef]

29. Rivera-Nieves J, Bamias G, Vidrich A, Marini M, Pizarro TT, McDuffie MJ, Moskaluk CA, Cohn SM, Cominelli F: Emergence of perianal fistulizing disease in the SAMP1/YitFc mouse, a spontaneous model of chronic ileitis. Gastroenterology 2003; 124: 972-982.[Medline] [CrossRef]

30. Takedatsu H, Mitsuyama K, Matsumoto S, et al: Interleukin-5 participates in the pathogenesis of ileitis in SAMP1/Yit mice. Eur J Immunol 2004; 34: 1561-1569.[Medline] [CrossRef]

31. Bamias G, Martin C, Mishina M, Ross WG, Rivera-Nieves J, Marini M, Cominelli F: Proinflammatory effects of TH2 cytokines in a murine model of chronic small intestinal inflammation. Gastroenterology 2005; 128: 654-666.[Medline] [CrossRef]

32. Olson TS, Reuter BK, Scott KG, et al: The primary defect in experimental ileitis originates from a nonhematopoietic source. $\mathrm{J}$ Exp Med 2006; 203: 541-552.[Medline] [CrossRef]

33. Reuter BK, Scott KG, Meddings JB, Cominelli F, Ernst PB, Pizarro TT: The SAMP1/yitfc mouse displays spontaneous gastric inflammation and represents a viable model to study Crohn's gastritis. 2005; 128: A209.

34. Olson TS, Bamias G, Naganuma M, et al: Expanded B cell population blocks regulatory $\mathrm{T}$ cells and exacerbates ileitis in a murine model of Crohn disease. J Clin Invest 2004; 114: 389-398.[Medline]

35. Gorfu G, Rivera-Nieves J, Hoang S, et al: Beta7 integrin deficiency suppresses B cell homing and attenuates chronic ileitis in SAMP1/YitFc mice. J Immunol 2010; 185: 5561-5568.[Medline] [CrossRef]

36. Mishima Y, Ishihara S, Aziz MM, et al: Decreased production of interleukin-10 and transforming growth factor-beta in Toll-like receptor-activated intestinal B cells in SAMP1/Yit mice. Immunology 2010.

37. Matsumoto S, Hara T, Nagaoka M, Mike A, Mitsuyama K, Sako T, Yamamoto M, Kado S, Takada T: A component of polysaccharide peptidoglycan complex on Lactobacillus induced an improvement of murine model of inflammatory bowel disease and colitis-associated cancer. Immunology 2009; 128: e170-e180. [Medline] [CrossRef]

38. Matsumoto S, Hara T, Hori T, Mitsuyama K, Nagaoka M, Tomiyasu N, Suzuki A, Sata M: Probiotic Lactobacillus-induced improvement in murine chronic inflammatory bowel disease is associated with the down-regulation of pro-inflammatory cytokines in lamina propria mononuclear cells. Clin Exp Immunol 2005; 140: 417-426.[Medline] [CrossRef]

39. Pagnini C, Saeed R, Bamias G, Arseneau KO, Pizarro TT, Cominelli F: Probiotics promote gut health through stimulation of epithelial innate immunity. Proc Natl Acad Sci U S A 2010; 107: 454-459.[Medline] [CrossRef]

40. Bamias G, Okazawa A, Rivera-Nieves J, Arseneau KO, De La Rue SA, Pizarro TT, Cominelli F: Commensal bacteria exacerbate intestinal inflammation but are not essential for the development of murine ileitis. J Immunol 2007; 178: 1809-1818.[Medline] 